\title{
PJIEE
}

\section{REPOSITIONING CULTURE IN TEACHING TARGET LANGUAGE: LOCAL CULTURE OR TARGET CULTURE?}

\author{
by \\ Hieronimus Canggung Darong \\ Universitas Katolik Indonesia Santu Paulus \\ hieronimusdarong@gmail.com \\ Sebastianus Menggo \\ Universitas Katolik Indonesia Santu Paulus \\ sebastian.pradana@gmail.com
}

Received: August 10, 2021,

Reviewed1:September5, 2021

Accepted: October 23, 2021, reviewer: August 10, 2021

reviewed2: October 17, 2021

published: October 28, 2021

\begin{abstract}
:
The role of culture in teaching target language is undeniable. This article belongs to a literature review. As such, it deals with the reviews of culture integration in English Language Teaching. The article provides the conflicting findings of teaching target language with local culture or target culture along with the reasonable reasons for each. The writers adopt the systematic way of doing literature review consisting of four steps namely designing the review, conducting the review, analyzing, and writing the review. Drawing from the review of the progress reports in the field, the writer recommends an intermediary for prospective English Language Teaching accommodating both local and target culture in question. Recomendations for future research studies are highlighted at the end.
\end{abstract}

Key words: Teaching, local culture and target culture.

\section{INTRODUCTION}

Teaching as imparting knowledge is a global phenomenon and goes through level of education. For many English teachers, teaching English or any subjects refers to controlling the class, delivering information as porposed in the curriculum, usually through talking or textbooks, evaluating and scoring (Blazar \& Kraft, 2017; Hafen et al., 2015; Pang, 2015; Tans, 2010). Despite its global effects, it must be replaced by a more challenging and effective one.

The strong reliance on the conception of teaching was on Farrell's finding (2015) emphasizing on an idea that teaching is what you know rather than on the race, culture and ethnicity you belong to. Pushing further, regarding the effectiveness, it should be regarded as a 
process of making students' strong willingness to learn. In this respect, the result of teaching might make the students better to learn actively. Consequently, it is more complex and complicated than learning. The reason is not because of having more knowledge as well as information on what and how to teach but rather than considering the ultimate goal, that is making the students to be active in learning. As such, there is an implication that the teacher should have more than the students. They have to read and learn to make the studens learn (Tans, 2010).

Moving to English Language Teaching (ELT) ahead, both as second language and foreign language, it has become the research focus. Some basic ideas related to what and how teaching are have been proposed along with approaches, methods, techniques following the great shift of paradigm, idea or even new conception of ELT. Yet, the discussion is still, in fact, becoming the point of interest regarding to its practice in the field. Let alone the countries as Indonesia considering English as a foreign or "second" language. English has been formally taught for far too long before and yet, in fact, it is still considered as the most diffucult subject to get along with. What is the problem actually?

This article presents a discussion on teaching- learning process of English language and culture which is definitely linked to it in question. The choice of adapting the target culture or the local culture as a context in English Language Teaching is outlined. Conceptual frameworks and some research findings are the basis to go to the conclusion and recomendation for the teaching practice and future prospective research studies. For that reason, the authors have decided to present and discuss the following topics as guideline of systematic reviews: (1) what is target Culture as a context? (2) what is local culture as a context?

\section{METHOD}

This study belongs to a literature review under the Snyder's (2019) method of systematic literature review consisting of four steps that are designing the review, conducting the review, analyzing, and writing the review were employed by the writers. The data were obtained from books and scientific articles published in national and international journals that subsequently highlighted following the steps of the method in question.

Premise Journal Volume 10 No 2, October 2021, e-ISSN: 2442-482x, p-ISSN: 2089-3345, page 250-266 
The writers gained the digested data from articles and books published in reputable journal both national and international. In this respect, the authors employed peculiar keywords and considered some specific criteria in searching articles. The criteria dealt with the indexed status of the publication, year of the publication, and the topic.

The criteria of the journals were indexed by Sinta, Scopus, or Web of Science. Meanwhile, for the books, the writers used some relevant books regardless of their publication years. This was intentionally done with a consideration that the chosen books were still up to date up to the present time. Both articles and books discussed culture, target, and local culture in the context of teaching English as the target language.

\section{FINDING AND DISCUSSION}

\section{Target Culture as a context}

As a term, culture is a broad concept. It deals with the ways of life such as beliefs, concepts, habits, behaviour, principles, and everything we learn to do. For some decades up this present time, the relation between language and culture in teaching- learning process has been broadly discussed even debated. As such, there is no fixed conception and formula regarding what and how it should be. Yet, it is invetably that there is a close relation between the two terms. Language might be loss if there is no culture. On the other way around, the culture does not have formula if there is no language (Jiang, 2010). Likely, a report on language and culture has conffirmed that they are so interwoven. In this regard separating them would lose the significance of their own (Huda, 2015; Lindahl \& Watkins, 2015).

To add on, Choudhury (2014), Jabeen \& Shah, Sayed (2011), Mahmoud (2015), Mejía (2016), Shin, Eslami, \& Chen (2011) and Siefert, Salas, \& Amico (2015) have assesrted a very interesting opinion that is language is socially constructed and shared meaning system. The language meaning might not be found in the language itself or its users but on its community who has used it. Putting it differently, a language has a meaning and is socially constructed. One's interpretation on language always relates to a context where social experiences might occur. Moving further, one constructs his/her knowledge, through engaging with others, the language must be there. As such, actions, experiences, and life patterns determine him/her of being more or less.

In teaching context, what and how to teach the students should be connected to culture.

Premise Journal Volume 10 No 2, October 2021, e-ISSN: 2442-482x, p-ISSN: 2089-3345, page 250-266 Copyright@2021 
In this respect, a teacher should teach his/her lesson by referring to something and that something is culture (Michelson, 2017). It is, therefore, the importance of cultural in teachinglearning language is an absolute. Referring the shift of the teaching toward the learning, (Limberg (2015), Miska, Szőcs, \& Schiffinger (2017) Yang \& Li (2019) have already reminded that culture awarness plays a vital role in the classroom activities. Likely, aside from English as the target language, Couper and Watkins, (2016) have emphasized the need to study target culture for foreign Language learners. Language seems senseless if the learners do not know anything about the people who speak that language.

Along the line of this argument, English learners are still struggling with the mastery of basic linguistic forms. They might success or make errors in their language production. For errors, they do not only appear as the insufficient knowledge of target language (L2) but also of insuffiecient knowledge of target culture. As such, the former in question might occur both in written and spoken mode resulting from linguistic and culture transfer of L1 to L2 (Dinamika \& Hanafiah, 2019; Fadilah, 2019; Fitria, 2018; Fitria, 2020; Kalee, Rasyid, \& Muliastuti, 2018; Setiyorini, Dewi, \& Masykuri, 2020). This is to say that to treat the errors, English learners should pay attention with both the linguistics forms and culture norms of the target language users.

Learning English as the target language does not only deal with syntactical aspects, phonological, and morphological (linguistic domain) but also learns the culture and the pragmatic rules of L2 users (Kadarisman, 2015). As confirmed by Brown (2001), if one successfully learns a language, he/she automatically succeds to learn something of the speakers of that language. To attain this, target language (English) learners should have both language and culture competence in their language production. Having insufficient knowledge of those two can create the so-called pragmatic errors (Gunduz, 2016; Saleem, Anjum, \& Tahir, 2021; Zhu, 2012; Stukan, 2018; Brown \& Levinson, 1978). Similarly, Mahmud (2019), Naoko Taguchi (2012) and Naoko, Taguchi \& Cmu (2011) have revealed that pragmatic errors might occur as the wrong use of any linguistic forms and misunderstanding of what is meant by what is said in context. Thus, the culture of target language users is very influential in learning their language.

Therefore, of greater importance in teaching English as the target language is making use of its culture as a teaching context. English teachers should teach their students the culture 
of L2 (Couper \& Watkins, 2016; Lindahl \& Watkins, 2015; Mahmoud, 2015; Marhamah, Daud, \& Samad, 8AD; Miska et al., 2017; Tajeddin \& Pezeshki, 2014; Yang \& Li, 2019) to put the language barriers away and help them to do a culture adjustment regarding their language production. Likely, since language and culture are interrelated, teacher should give a space in which the target culture is embedded (Couper \& Watkins, 2016; Limberg, 2015; Lindahl \& Watkins, 2015; Tajeddin, 2012).

Moreover, what to teach is automatically and usually links to culture. The lesson is about something and it is cultural (Mahmoud, 2015; Siegel, 2014). Saying it differently (Tin, 2014; Yang \& $\mathrm{Li}, 2019$ ) have proposed that if one wants to learn a certain language, he/she has to learn its people and its culture. It does not make any sense to learn another language independently without learn its culture (Tajeddin 2012). Then, it is very crucial to pay attention on the target culture as one teaches and learns a target language. Since it is really urgent, culture might be considered as the fifth skill to master. For teachers, the skill that has to go along with the teaching skill that might empower the learners to master the language easily.

\section{Local Culture as a context}

In contrast with the first in which the target culture is embeded in teaching- learning process, the second view is concerned with the local culture's role in the teaching-learning language. As such, the culture in question refers to any proper products, behaviour, visiable and non- visible things which might be used in ELT. As such, this second view proposes that the local culture employment in teaching- learning context is useful and of benefit for the learners' language mastery. In the meantime, the target culture is rejected for its inclusion in language teaching-learning context.

The rejection is concerned with the learners' burden and a consideration of English as lingua franca. The learners might view a strange phenomenon as they experience different culture from what they imagine. In addition, they might have negative reactions and feel shocked due to unfamiliar content or context found in the target culture. Briefly, their burden would be more cognitively and linguistically. Aside from those, the learners are equipped with the feeling of alienation and strangeness. Therefore, there is a must to teach learners by considering their locality (Mahmoud, 2015).

Premise Journal Volume 10 No 2, October 2021, e-ISSN: 2442-482x, p-ISSN: 2089-3345, page 250-266 Copyright@2021 
Meanwhile, progress reports in the field have extensively discussed and widely debated concerning with the local culture in teaching and learning language. There have been many studies carried out resulting from curiosity whether its use is relevant or not. Many studies have indicated that local culture is definitely needed to be integrated in the process of teaching. For example, the studies of Chan (2013), Nicholas (2015), Siegel (2014) which found that using unfamiliar context might cause the linguistic problems. On the other way around, context familiarity by utilizing local aspect is beneficial and helpful for English learners. The studies have also highlighted the term processing overload of having linguistic and target culture at the same time. This means that local culture which is more familiar and preferable to use than the target one. Focusing on students own culture instead of dealing with the discourse of target culture in EFL classroom might facilitate the target language acquisition.

Along the line the studies, teachers should understand, contextualize and adapt English language that is internationally used and is as a lingua franca in teaching context. Diversity and complexity of various ELT context and its effect in teaching process are helpful. Context diversity and complexity, in this sense, are concerned with the inclusion of the learners' local culture (Cocks, Vetter, \& Wiersum, 2017; Shin et al., 2011; Tin, 2014). In this regard, it is necessarly done to reconstruct the local knowledge by placing in context and through function and meaning it might serve.

While the mentioned studies concentrated on the necessity of local culture as a context of teaching, there was moving a step forward emphasizing the concrete insertion of local culture in the textbooks. Research reports on English language text books have strongly argued that the course should rely on country's enviorenment reflecting people's life, belief, experinces, manner and interest. Local-based teaching materials should be made, as they are percieved more culturely or experintially than other course books written by native speakers from English speaking contries (Mahmud, 2019; Snodin, 2015; Suswandari, 2017). To add on, the setting of English Language Teaching (ELT) must take place in original source of the learners. To achieve more effective learning experinces, the integration of learners' local context and culture should be carried out. As such, it could be as a bridge of good learning process; without any obstacles, or if any, learning problems can be solved smoothly (Byram, 1993; Meihami \& Khanlarzadeh, 2015; Syahri \& Susanti, 2016).

Premise Journal Volume 10 No 2, October 2021, e-ISSN: 2442-482x, p-ISSN: 2089-3345, page 250-266 Copyright@2021 
Focusing on the identity awareness, Reed, Said, Davies, Bengsch, \& Reed (2019), Hajar (2017), and Teng (2020) have proposed and encouraged learners of English to talk using their local materials in order to be aware of their own culture indentity in global context. Likely, Motteram (2016) has suggested to insert the locality in English textbooks for the sake of identity in $21^{\text {st }}$ century. More particularly, those research findings have indicated the significant inclusion of local context in English teaching-learning and have provided an effective way of facilitating learner's identitiy to living globally.

To date, a relevant question is what happens in Indonesian context? There have been many studies carried out regarding the use of local culture in English Language Teaching. For example, Alamsyah (2016) did a research on the significance of integration local context or culture in curiculum. This is supported by Kuntoro, Peterson, and Slaughter (2017) who emphasized the importance of local culture integration in teaching- learning process. As such, the insertion might serve a function to improve and maintain the spirit of nationalism.

Meanwhile, other studies have highlighted beliefs, values and local wisdom in classroom instruction. Pushing further, the study offered an alternative instructional method that incorporated with the three in question in classroom context (Suswandari, 2017). As such, aside from improving English, it is beneicial for bulding a good character. Along the line of this findings, Mahmud (2019), Syahri and Susanti (2016) have proposed the development of English course books which relies much on environmental eduaction. These cover learners' activities outside school, ethic, conduct, and manner in terms of valuing diversity and nationalism. At this point, it is necessary to put a great attention on the local culture employment during teaching learning process. The teachers should localize their pedagogy which might be beneficial in designing orientation, tolerance and personality development.

Overall, the local culture insertion in teaching is of benefit for learners' English language mastery and learners' attitude. Aside from English as a lingua franca, the local culture employment might maintain learners' identity, ethic, conduct and manner in global context. In a more profound sense, the insertion, as highlighted by previous studies, would be of insightful to reduce the probability of having assimilation as well as alienation along with the linguistic concern of the target language.

The issue of culture is a complex. Bringing it to English Language Teaching, it is not a simple case. Choice of adapting target or local culture as a context in English Language 
Teaching, in fact, is still debateable. Progress reports in the field have revealed differently following the benefits and the role of their own (Shin et al., 2011; Wolthuis, Bloemert, \& Tammenga-helmantel, 2020). Therefore, as an English teacher, there should be an extra effort to realign his/her ways of teaching along with the instructional materials, techniques and approach used. More importantly, both teacher and students should attain the learning goals and be able to teach and learn language properly both in use and usage as well.

With respect to the inclusion of the target culture, findings of previous studies have claimed that the necessity of target context (culture) in English teaching-learning relies on target language learning acceleration and the consideration of expanding learners' cultural awareness. Besides, it should be done to incorporate global and multicultural perspectives (Ridha \& Maad, 2016). Teaching target culture in English language classroom aims at evolving responsive action. An extensive and a more all- embracing omprehensive experiences of target culture in ELT (English Language Teaching) might strengthen the engagement with global citizenships. In addition, the previous studies suggesting the inclusion of target culture have claimed the insertion of local context in ELT suffers from limitation. One of the central issue of such inclusion deals with the dereliction to relate the English language to the cultures of other countries and to develop worlwide links. Therefore, such constraint is solved by the inclusion of global culture materials. In this context, language awareness must be oriented to the diversity through which learners might overcome the barriers of linguistic and communicative performances (Lourenço, Andrade, \& Sá, 2017).

Yet, it is necessary to note that that the target culture inclusion in language teaching is not limited to objects, facts and artefacts', always handing out culture as steady, congruent 'facts' (Canale, 2016). It can not only promote peripheral comparisons between 'our' and 'their' cultures without promoting the diversity or evoking one's criticality. In this regard, better cultural inclusion should represent the culture of target language and other international culture values or manner as well that subsequently notify and escalate the global citizenship attitude (Davidson \& Liu, 2018).

To add on, alongside the global citizenship, intercultural citizenship education and multicultural values are another benefits of the target culture inclusion. As such, learning referring to others, extensive acknowledgement developing with life experience and action reflecting in personal changes or activities of a particular community at a range of global lamina

Premise Journal Volume 10 No 2, October 2021, e-ISSN: 2442-482x, p-ISSN: 2089-3345, page 250-266 Copyright@2021 
and borderless should be a must (Baker, Fang, \& Baker, 2020; Byram, 1993; Porto, 2017; Porto, Houghton, \& Byram, 2018; Setyono \& Widodo, 2019) At this point, the inclusion of the target culture in ELT classroom might develop social manner and a positive persepectives regarding the global language community. In more practical sense, the learners should be taught the target culture as they intend to socialize themselves with other people in this globe. Learning target language essentially includes learning its culture as they are intimately related (Hajar, 2017).

Meanwhile, regarding the inclusion of local culture, previous findings have convinced us that the use of local culture is quite more effective in ELT. Standing on sociocultural theory, the learners' social context is a vital aspect in learning English as the target language. Therefore, cultures and experiences of the learners should be utilized in the process of teaching and learning. Moreover, local cultures or contexts possess rightfulness which cannot be regarded as marginal or minor status. Consequently, there is a must for materials or instructional practices to take the locality into account which can assist and or facilitate learners in learning or acquiring the target language. Aside from language learning and language acquisition, another important consideration is the rejection (negative attitude) of the target language they learn as they find unfamiliar context. Furthermore, English language is regarded as a lingua franca or even more and should be contextualized where the people learn it (Hult, 2017; Jabeen \& Shah, Sayed, 2011).

Likely, ELT should ideally go to a context of factual life or local context in which students are regulated. Then, language and schematic knowledge are learnt and constructed socially and culturally banded (Hafner, 2015). In terms of schematic knowledge, he elaborates that foreign language learners, for instance, are determined by their mother tongue's culture. He also assumed that students sometimes have pitfalls to comprehend the learning materials due to the unfamiliar context such lexical and cultural items that are unfamiliar to them if teaching target language utilizing target culture.

To be noted, adapting local culture in English Language Teaching is regarded as a way of enhancing students' mastery in English language and stirring good conducts. The more teaching-learning process relies on local- authentic materials, the better values might have. Employing local context, beside helping learners to understand and know what to say, it unconsciously builds the learners' good character The value contained in local culture is quite natural and contextual for language mastery and character building. 
By and large, the important role of culture in English Language Teaching (ELT) is definetely disputed. Some have believed that target culture (TL) is of benefit to be included as the consideration of global citizenship and cross-culture understanding. Yet, for those concerning with local culture relies on the consideration of English as lingua franca and selfidentity. Besides, local culture along with its local (first) language is badly claimed helpful in acquiring the target language.

Interestingly, different from the conflicting ideas mentioned, viewed from cognitive perspective, inclusion of a target culture againsts students' familiarity and experiential knowledge. Therefore, it would be more beneficial and helpful as the materials rooted to their prior or preparatory knowledge. Moreover, learners can be encouraged to study a target language by provoking them to have a good attitude and build the self- reliance or confidence toward the target culture by inserting or adapting a local context in teaching, (Chan, 2013). As such, both local and target culture play important role in English Language Teaching.

To put it differently, English Language Teaching (ELT) should consider both local and target cultural context. Students should be aware of their own local cultures enriching authentic linguistic knowledge and social enactments as learning English (a target language), thereby having a more meaningful learning. Meanwhile, there is a need to teach culture of the learnttarget language to live in global community. The more we use both, the more powerfull our teaching is and the better target language learners have. Moreover, it has been expostulated by previous studies that learners do not need to rely on the English native speakers' culture to thrash out or negotiate meaning and communicate with other users of English. Effective L2 learners do not necessarily learn have to promote the whole target culture. Meanwhile, other studies have highlighted that to make learners more global in terms of knowledge, ways of thinking, social adaptation, they should be introduced with target culture. At this point, both are acceptable in the context of teaching-learning English.

Along the line of this statement, regardless the pro and cons and or the strength and weakness, to date, what is more important is the proportion or the balance in which target culture and local culture is inserted. In this regard, as a target language teacher, he/she should be more resourceful and knowledgable to place the instances of a target culture or local culture in teaching. A balance and a proportional combination of localized and native-speaking, and internationalised culture forms is a proxy or a choice to cope with the issue in question. What

Premise Journal Volume 10 No 2, October 2021, e-ISSN: 2442-482x, p-ISSN: 2089-3345, page 250-266 Copyright@2021 
to teach needs to be context-based, yet it must invlove the global or target culture to scaffold, facilitate learners' intercultural performance and competence as well. The teacher should be encouraged to use teaching materials or textbooks to make sure that his/her students are exposed to global, target, and local cultural components.

By and large, inserting culture in the English Language Teaching (ELT) seems not an easy job. There must be, to certain extent, a degree of conflict between what is global and what is local in teaching-learning process. Yet, a mixture of the two in question while considering the proportion of each and learners' needs is essential. In this regard, it is very important to have a class in the sense that the learners fell comfortable in mastering the target language resulting from the teaching activities. Although, the inclusion of culture, whether target or local culture in ELT is little bit challenging, the proportion of what and how to utilize them in teaching-learning process might be an intermediary of this challenge. In addition, having pointed out sociocultural theory supporting the context playing a vital role in teaching and learning language, the employement of culture does not only involve the target culture but also the local one following the needs of teaching and learning.

Leaving the context of target or local culture in teaching- learning process aside, another important aspect to consider is the teaching itself. English Language Teaching language should be regarded more as mediating students in learning than solely telling them a piece of information. Therefore, teaching should be caaried out in such a way that it can result in students' active learning experiences. The employment of target and local context in teaching English should be in balance and be carried out wisely to reach the result in question and to have more powerfull and meaningful learners' mind and character as well. Such consideration of teaching might empower learners to think globally and act locally.

\section{CONCLUSION AND IMPLICATION}

The position of culture is a central issue in in English teaching-learning process. The hottest issue is that the choice of target or local culture to be integrated. As such, previous studies have found different findings. Some have agreed that the target culture must be delivered for the learners with the consideration of global citizenship and interculture competence of living in the global community. Differently, for those saying that local culture needs to be inserted in teaching learning process relies on the consideration of English as a 
lingua franca, language acquisition, and national identity. Regardless the conflicting findings, combination of the two in question might be better. In this respect, both are acceptable and can be utilized in English Language Teaching. Then, As an English teacher, he/she must be more resourceful and knowledgeable to know what and how to teach. Besides, he/she has to be able in managing the proportion or balance of the two following the learners' needs. A good proportion of both is an intermediary of the conflicting findings.

More importantly, future research studies might be better and more benefecial to bring closer to the integration of local culture into typography of national curiculum, textbooks along with the assessment process. Briefly, the extent of culture embeded in national curiculum and the teacher ways of doing assessment is more challenging issue to deal with. As such, the studies might yield important aspects and broaden views of contextualizing the target language teaching and learning.

\section{BIO-PROFILE}

Hieronimus Canggung Darong graduated from STIBA Malang in 2000. He got his master degree from UNDIKSHA Singaraja Bali in 2012 and doctoral degree in the English education department of Universitas Negeri Malang in 2020. His research interest includes discourse analysis, language learning and teaching, and language and culture studies. Corresponding email: hieronimusdarong@gmail.com

Premise Journal Volume 10 No 2, October 2021, e-ISSN: 2442-482x, p-ISSN: 2089-3345, page 250-266 


\section{REFERENCES}

Alamsyah, A. (2016). Unika Atma Jaya, 6-8 April 2016. In The Use of Local Short Story in English Language Learning (A Literary Review on The Use Of Local Sources As An Alternative Teaching Media In Efl) (pp. 286-290).

Baker, W., Fang, F. G., \& Baker, W. (2020). ' So maybe I' m a Global Citizen ': Developing Intercultural Citizenship in English Medium Education. Language, Culture and Curriculum, 34(1), 1-17. https://doi.org/10.1080/07908318.2020.1748045

Blazar, D., \& Kraft, M. A. (2017). Teacher and Teaching Effects on Students' Attitudes and Behaviors. Educational Evaluation and Policy Analysis, 39(1), 146-170. https://doi.org/10.3102/0162373716670260

Brown, P., \& Levinson, S. C. (1987). Politeness: Some universals in language usage. Cambridge, UK: University Press.

Brown, H. D. (2001). Teaching by Principle and Interactive Approach to language pedagogy. New York: Longman Inc.

Byram, M. (1993). Language and Culture: The Need For Integration. In M. Byram (Ed.), Germany, It's Representation In Textbooks For Teaching German In Great Britain (Pp. 3-16). Frankfurt Am Main: Diesterweg.

Canale, G. (2016). (Re) Searching Culture in Foreign Language Textbooks, or the Politics of Hide and Seek. Language, Culture and Curriculum, 29(2), 1-20. https://doi.org/10.1080/07908318.2016.1144764

Chan, J. Y. H. (2013). The Role of Situational Authenticity in English Language Textbooks. RELC Journal, 44(3), 303-317. https://doi.org/10.1177/0033688213500583

Choudhury, R. U. C. L. (2014). The Role of Culture in Teaching and Learning of English. Express, an International Journal of Multi Disciplinary Research, 1(4), 1-20. Retrieved from www.express-journal.com

Cocks, M., Vetter, S., \& Wiersum, K. F. (2017). From universal to local: perspectives on cultural landscape heritage in South Africa. International Journal of Heritage Studies, 24(1), 1-19. https://doi.org/10.1080/13527258.2017.1362573

Couper, G., \& Watkins, A. (2016). Teaching the Sociocultural Norms of an Undergraduate Community of Practice. Tesol Journal, 7(1), 4-39. https://doi.org/10.1002/tesj.187

Davidson, R., \& Liu, Y. (2018). Reaching the World Outside: Cultural Representation and Perceptions of Global Citizenship in Japanese Elementary School English Textbooks, 33(1), 1-19. https://doi.org/10.1080/07908318.2018.1560460

Dinamika, S. G., \& Hanafiah, R. (2019). Syntactical Error Analysis on Report Text. Journal of Applied Linguistics and Literature, 4(2), 120-129. https://doi.org/: http://dx.doi.org/10.33369/joall.v4i2.7681

Fadilah. (2019). An Analysis of Error on the Use of Simple Past Tense in Writing Narative Text of 42 State SMKIn Jakarta. Jurnal Bahasa Dan Komunukasi, 11(1), 15-24. Retrieved from http://ejournal.bsi.ac.id/ejurnal/index.php/wanastra\%0AAN

Premise Journal Volume 10 No 2, October 2021, e-ISSN: 2442-482x, p-ISSN: 2089-3345, page 250-266 Copyright@2021 
Farrell, T. S. C. (2015). It 's Not Who You Are! It's How You Teach! Critical Competencies Associated with Effective Teaching. RELC Journal, 45(1), 1-10. https://doi.org/10.1177/0033688214568096

Fitria, N. T. (2018). Error Analysis Found in Students' Writing Composition of Simple Future Tense. ELS Journal on Interdisciplinary Studies on Humanities, 1(3), 240-251. Retrieved from http://journal.unhas.ac.id/index.php/jish

Fitria, T. N. (2020). Spelling Error Analysis in Students' Writing English Composition. Journal GEEJ, 7(2), 240-254.

Gunduz, N. (2016). Sociopragmatic Elements and Possible Failure in EFL Teaching. Dil Dergisi $\bullet$ Sayi, 167(1), 49-66.

Hafen, C. A., Hamre, B. K., Allen, J. P., Bell, C. A., Drew, H., \& Pianta, R. C. (2015). Teaching through Interactions in Secondary School Classrooms : Revisiting the Factor Structure and Practical Application of the Classroom Assessment Scoring System Secondary. Journal of Early Adolescence, 35(5-6), 651-680. https://doi.org/10.1177/0272431614537117

Hafner, C. A. (2015). Remix Culture and English Language Teaching: The Expression of Learner Voice in Digital Multimodal Compositions. Tesol Journal, 49(3), 486-509. https://doi.org/10.1002/tesq.238

Hajar, A. (2017). Identity, Investment and Language Learning Strategies of Two Syrian Students in Syria and Britain. Language, Culture and Curriculum, 30(3), 1-15. https://doi.org/10.1080/07908318.2017.1317266

Huda, T. (2015). Reflection of Rhetorical Pattern in the Introduction of Academic Research Reports. In ICTTE FKIP UNS (pp. 1657-1662). FKIP UNS.

Hult, F. M. (2017). More than a Lingua Franca: Functions of English in a Globalised Educational Language Policy. Language, Culture and Curriculum, 30(3), 1-18. https://doi.org/10.1080/07908318.2017.1321008

Jabeen, F., \& Shah, Sayed, K. (2011). The Role of Culture in ELT: Learners' Attitude towards the Teaching of Target Language Culture. European Journal of Social Sciences, 23(4), 604-613. Retrieved from https://www.researchgate.net/publication/260045647

Kadarisman, E. (2015). From Description to Explanation: Essays in Linguistics and Applied Linguistics. Linguistic Society of Indonesia.

Kalee, S., Rasyid, Y., \& Muliastuti, L. (2018). Error Analysis on the Use of Letters Students in Indonesian Papers Written by Thai Students. Journal of English Language Studies, 3(1), 113-124. Retrieved from http://jurnal.untirta.ac.id/index.php/JELS\%0AError

Kuntoro, I. A., Peterson, C. C., \& Slaughter, V. (2017). Culture, Parenting, and Children 's Theory of Mind Development in Indonesia. Journal of Cross-Cultural Psychology, 48(9), 1389-1409. https://doi.org/10.1177/0022022117725404

Limberg, H. (2015). Principles for Pragmatics Teaching: Apologies in the EFL Alassroom. ELT Journal Volume, 69(3), 275-285. https://doi.org/10.1093/elt/ccv012

Premise Journal Volume 10 No 2, October 2021, e-ISSN: 2442-482x, p-ISSN: 2089-3345, page 250-266 Copyright@2021 
Lindahl, K., \& Watkins, N. M. (2015). Creating a Culture of Language Awareness in Content-Based Contexts. Tesol Journal, 6(4), 777-789. https://doi.org/10.1002/tesj.223

Lourenço, M., Andrade, A. I., \& Sá, S. (2017). Teachers' Voices on Language Awareness in Pre- Primary and Primary School Settings: Implications for Teacher Education. Language, Culture and Curriculum, 31(2), 113-127. https://doi.org/10.1080/07908318.2017.1415924

Mahmoud, M. M. . (2015). Culture and English Language Teaching in the Arab World. Adult Learning, 25(3), 66-72. https://doi.org/10.1177/1045159515573020.

Mahmud, Y. S. (2019). The Representation of Local Culture in Indonesian EFL Textbooks: Rationales and Implications. Indonesian EFL Journal (IEFLJ), 5(2), 61-72. https://doi.org/10.25134/ieflj.v5i2.1727.Received

Marhamah, R., Daud, B., \& Samad, I. A. (8AD). Integrating Target Language Culture into Teaching-Learning EFL. ENGLISH EDUCATION JOURNAL (EEJ, 4(488-502).

Meihami, H., \& Khanlarzadeh, M. (2015). Pragmatic Content in Global and Local ELT Textbooks : A Micro Analysis Study. SAGE Open, 1-10. https://doi.org/10.1177/2158244015615168

Mejía, G. (2016). Language usage and culture maintenance: a study of Spanish-speaking immigrant mothers in Australia. Journal of Multilingual and Multicultural Development ISSN:, 37(1), 23-39. https://doi.org/10.1080/01434632.2015.1029931

Michelson, K. (2017). Teaching Culture as a Relational Process through a Multiliteraciesbased Global Simulation. Language, Culture and Curriculum, 31(1), 1-20. https://doi.org/10.1080/07908318.2017.1338295

M. B. Miles, A. M. Huberman, and J. Saldaña (2014) Qualitative Data Analysis, 3rd Editio. London: SAGE Publication

Miska, C., Szőcs, I., \& Schiffinger, M. (2017). Culture's Effects on Corporate Sustainability Practices : A Multi-domain and Multi-level view. Journal of World Business, 53(2), 263-279. https://doi.org/10.1016/j.jwb.2017.12.001

Motteram, G. (2016). Membership , Belonging, and Identity in the Twenty-first Century. ELT, 70(2), 150-159. https://doi.org/10.1093/elt/ccw001

Nicholas, A. (2015). A Concept-based Approach to Teaching Speech Acts in the EFL Classroom. ELT Journal Volume, 69(4), 383-394. https://doi.org/10.1093/elt/ccv034

Pang, M. A. Y. (2015). Pedagogical Reasoning in EFL / ESL Teaching : Revisiting the Importance of Teaching Lesson Planning in Second Language Teacher Education. Tesol Quarterly, (Teaching Issues), 246-263. https://doi.org/10.2167/la429.0

Reed, B. S., Said, F., Davies, I., Bengsch, G., \& Reed, B. S. (2019). Arabic Complementary Schools in England: Language and Fundamental British Values. Language, Culture and Curriculum, 33(1), 50-65. https://doi.org/10.1080/07908318.2019.1569674

Ridha, M., \& Maad, B. (2016). Awakening Young Children to Foreign Languages: Openness to Diversity Highlighted. Language, Culture and Curriculum, 29(3), 1-17.

Premise Journal Volume 10 No 2, October 2021, e-ISSN: 2442-482x, p-ISSN: 2089-3345, page 250-266 Copyright@2021 
https://doi.org/10.1080/07908318.2016.1184679

Saleem, T., Anjum, U., \& Tahir, S. (2021). The Sociopragmatic and Pragmalinguistic Strategies in L2 Pragmatic Competence : A Case of Pakistani ESL Learners. Journal of Intercultural Communication Research, 50(2), 1-22. https://doi.org/10.1080/17475759.2021.1877176

Setiyorini, T. J., Dewi, P., \& Masykuri, E. S. (2020). The Grammatical Error Analysis Found in Students' Composition. Lensa: Kajian Kebahasaan, Kesusastraan, Dan Budaya, 10(2), 218-233. https://doi.org/https://doi.org/10.26714/lensa.10.2.2020.218-233

Setyono, B., \& Widodo, H. P. (2019). The representation of Multicultural Values in the Indonesian Ministry of Education and Culture- Endorsed EFL Textbook: A Critical Discourse Analysis. Intercultural Education, 30(4), 383-397. https://doi.org/10.1080/14675986.2019.1548102

Shin, J., Eslami, Z. R., \& Chen, W. (2011). Presentation of local and international culture in Current International English-language Teaching Textbooks. Language, Culture and Curriculum, 24(3), 253-268. https://doi.org/http://dx.doi.org/10.1080/07908318.2011.614694 PLEASE

Siefert, B., Salas, S., \& Amico, M. M. D. (2015). “I Understand the Struggle ": Leveraging the Lived Experiences of African American Teachers in TESOL. Tesol Journal, 6(4), 731-750. https://doi.org/10.1002/tesj.188

Siegel, A. (2014). What should we talk about? The authenticity of textbook topics. ELT Journal, 68(4), 363-375. https://doi.org/10.1093/elt/ccu012

Snodin, N. S. (2015). Rethinking Culture Teaching in English Language Programmes in Thailand. RELC Journal, 47(3). https://doi.org/10.1177/0033688215609231

Stukan, D. (2018). Sociopragmatic Failure: Struggling with Cross-Cultural Differences in Communication. Open Journal for Anthropological Studies, 2(1), 27-36.

Suswandari. (2017). Incorporating Beliefs, Values and Local Wisdom of Betawi Culture in a Character-Based Education through a Design-Based Research. European Journal of Contemporary Education, 6(3), 574-585. https://doi.org/10.13187/ejced.2017.3.574

Syahri, I., \& Susanti, R. (2016). An Analysis of Local and Target Culture Integration in the English Textbooks for Senior High School in Palembang. Journal of Education and Human Development, 5(2), 97-102. https://doi.org/10.15640/jehd.v5n2a11

Snyder, H. (2019) Literature review as a research methodology: An overview and guidelines, J. Bus. Res, 104(July) 333-339. https://doi.org/10.1016/j.jbusres.2019.07.039.

Taguchi, N. (2012). The Effects of Practice Modality on Pragmatic Development in L2 Chinese. https://doi.org/10.1111/j.1540-4781.2014.12123.x

Taguchi, N. (2018). Description and Explanation of Pragmatic Development: Quantitative, Qualitative, and Mixed Methods Research. System, in Press, 1-10.

Taguchi, N., \& Cmu, B. H. (2011). Pragmatic Development as a Dynamic , Complex 
Process : General Patterns and Case Histories. The Modern Language Journa, 95(4), 605-627. https://doi.org/10.1111/j.1540-4781.2011.01246.x

Tajeddin, Z. (2012). Interlanguage Pragmatic Motivation : Its Construct and Impact on Speech Act Production. RELC Journal, 43(3), 353-372. https://doi.org/10.1177/0033688212468481

Tajeddin, Z., \& Pezeshki, M. (2014). Acquisition of Politeness Markers in an EFL Context : Impact of Input Enhancement and Output Tasks. RELC Journal, 45(3), 269-286. https://doi.org/10.1177/0033688214555357

Teng, F. (2020). Autonomy, agency , and identity in teaching and learning English as a foreign language. Journal of Education for Teaching, 00(00), 1-3. https://doi.org/10.1080/02607476.2020.1712913

Tin, T. B. (2014). A look into the local pedagogy of an English language classroom in Nepal. Language Teaching Research, 18(3), 397-417. https://doi.org/10.1177/1362168813510387

Wolthuis, F., Bloemert, J., \& Tammenga-helmantel, M. (2020). A Curriculum in Transition: TL/ L1 Use in Dutch EFL Literature Lessons. Language, Culture and Curriculum, 33(4), 335-350. https://doi.org/10.1080/07908318.2019.1697279

Yang, W., \& Li, H. (2019). Changing Culture, Changing Curriculum : A case Study of Early Childhood Curriculum Innovations in Two Chinese Kindergartens. The Curriculum Journal, 30(3), 1-19. https://doi.org/10.1080/09585176.2019.1568269

Zhu, W. (2012). Polite Requestive Strategies in Emails : An Investigation of Pragmatic Competence of Chinese EFL Learners. RELC Journal, 43(2), 217-238. https://doi.org/10.1177/0033688212449936 